\title{
Objective structured clinical examination, OSCEs: an advance in the teaching and learning process in the student's perception
}

\author{
Exame clínico objetivo estruturado, OSCE: um avanço no processo de ensino \\ e aprendizagem sob a percepção do estudante
}

Fabiana Aparecida Mayrink DE OLIVEIRA ${ }^{a}$ [ , Fernanda Ribeiro PORTO $^{a}$ (), Cleide Gisele RIBEIRO ${ }^{a *}$ (i),

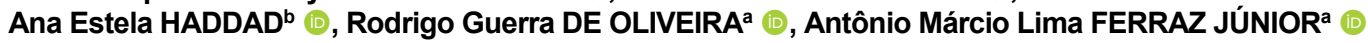

asUPREMA - Faculdade de Ciências Médicas e da Saúde de Juiz de Fora, Juiz de Fora, MG, Brasil bUSP - Universidade de São Paulo, São Paulo, SP, Brasil

\begin{abstract}
How to cite: de Oliveira FAM, Porto FR, Ribeiro CG, Haddad AE, de Oliveira RG, Ferraz Júnior AML. Objective structured clinical examination, OSCEs: an advance in the teaching and learning process in the student's perception. Rev Odontol UNESP. 2019;48:e20190027. https://doi.org/10.1590/1807-2577.02719
\end{abstract}

\section{Resumo}

Introdução: O OSCE é um método de avaliação de competências clínicas que tem obtido popularidade internacional na educação em Medicina e Odontologia.

Objetivo: 0 objetivo do presente estudo foi descrever as etapas de desenvolvimento do OSCE para o curso de graduação em Odontologia e relatar a percepção dos estudantes sobre este método de avaliação, em relação ao grau de dificuldade, tempo para realização de cada etapa, importância de cada estação, número de estações, organização do exame, bem como o tempo total para a realização do OSCE.

Material e método: Esta pesquisa foi um estudo observacional e transversal, composto pela realização do OSCE e posterior aplicação de um questionário avaliativo aos alunos que cursavam o quarto semestre do curso de Odontologia. Esses alunos possuíam conhecimentos básicos em um nível intermediário de competências, compatíveis com sua etapa de ensino.

Resultado: No que diz respeito ao número de estações, 43 (97,7\%) dos estudantes responderam que era apropriado, o processo da OSCE como um todo estava muito bem organizado ( $\mathrm{n}=25 ; 56,8 \%$ ), organizado ( $n=17 ; 38,6 \%)$ ou não muito organizado $(n=1 ; 2,27 \%)$ e sobre o tempo total do processo do OSCE, $29(65,9 \%)$ relataram que era apropriado; 10 (2,27\%) disseram que foi curto; 4 (9,09\%), que foi longo.

Conclusão: A percepção do aluno foi positiva, especialmente em relação à organização e ao tempo atribuído a cada estação. Além disso, os alunos consideraram que os tópicos e questões aplicados em cada estação eram relevantes.

Descritores: Educação em odontologia; estudantes de odontologia; percepção.

\begin{abstract}
Introduction: The OSCE is a method of clinical competencies evaluation that has gained international popularity in medical and dental education.

Objective: The purpose of the present study was to describe the stages of development of the OSCE for the undergraduate course in Dentistry and to report the students' perception about this method of evaluation, regarding the degree of difficulty, time for each stage, importance of each station, number of stations, organization of the exam, as well as the total time for the OSCE.

Material and method: This research was an observational and cross-sectional study, composed of the carry out of an OSCE and later application of an evaluative questionnaire to the students who were in the fourth semester of the Dentistry course. These students had basic knowledge and an intermediate level of competences, compatible with their stage of education.

Result: As regards the number of stations, 43(97.7\%) of the students responded that this was appropriate, OSCE process as a whole was very well organized $(n=25 ; 56.8 \%)$, organized $(n=17 ; 38.6 \%)$ or not very
\end{abstract}


organized $(n=1 ; 2.27 \%)$ and about the total time of the OSCE process, $29(65.9 \%)$ reported that it was appropriate; 10 (2.27\%) said that it was short; 4 (9.09\%), that it was long.

Conclusion: The student's perception was positive especially regarding to organization and the time attributed to each station. Furthermore, the students considered that the topics and questions applied in each station were relevant.

Descriptors: Dental education; dental students; perception.

\section{INTRODUCTION}

The clinical competence of dental students is usually assessed in terms of the number of case observations and/or assistance with a professor's treatment and their performance of procedures in the student dental clinic ${ }^{1}$. Traditional methods of assessment in dental education often concentrated on student knowledge and memorization abilities rather than on the cognitive skills needed for clinical practice. Traditional examinations also cannot assess how effectively higher level cognition is applied when performance-based criteria are involved ${ }^{2}$. Comprehensive assessment of students' academic performance plays an important role in educational planning?

Unlike the traditional methods, OSCEs (Objective Structured Clinical Examination) is a method for assessment of clinical competences ${ }^{4}$. The OSCE was introduced by Harden in 19755,6 and has attained international popularity in medical and health care education ${ }^{7,8}$. One of the main strengths of the OSCE examination is its inherent objectivity whereby the aim is to remove patient and examiner variation so that the only variable being examined is the ability of the candidate. These examinations involve students rotating around a series of pre-determined, specifically designed stations which assess clinical and communication competence. Examiners assess student performance objectively against pre-determined, structured criteria ${ }^{5}$.

This means that it is possible to examine a range of skills and disciplines and even to incorporate more than one skill or discipline simultaneously in the design of a particular station ${ }^{9}$. Examples of competences applicable to a range of disciplines include communication skills, aspects of anamnesis and biosafety. The disadvantages of the method are: greater exam preparation time; demanding in nature for both examiners and patients, and an OSCE is considered more cost-effective than other assessment methods ${ }^{10}$.

Assessment of student's perception must be explored to understand innovative strategies for the assessment of dental practice. Analysis of perceptions specifically about the educational value of an exam allows educators to know whether a method is very successful in promoting important competences, such as the application of knowledge and solution of problems ${ }^{11}$. Studies have found evidence that dental students perceived OSCE as an efficient and significant method of assessment, as well as a positive learning experience ${ }^{12-14}$

The Dentistry Course at the School of Medical and Health Sciences of Juiz de Fora (SUPREMA) has been using OSCE since 2014, with the intention of adopting an evaluative approach with focus on the clinical competence. As OSCE is a form of evaluating the competences in all their domains, it is fundamental to analyze the perception of students about this practice. Therefore, the aim of the present study was to describe the stages of development of the OSCE for the undergraduate course in Dentistry and to assess the Dental students' perception of the OSCE regarding to the degree of difficulty, time for each stage, importance of each station, number of stations, organization of the exam, as well as the total time for the OSCE.

\section{METHOD}

The study involved the implementation of the OSCE and the subsequent application of an evaluation questionnaire to the students who were in the fourth semester of the Dentistry course of the School of Medical and Health Sciences of Juiz de Fora (SUPREMA), Minas Gerais, Brazil. These students $(n=44)$ had basic knowledge and an intermediate level of competences, compatible with their stage of education. The Dentistry course is a four-year long program. All the students were invited and agreed to answer the questionnaire. The inclusion criteria were to be 
in the fourth period and to have carried out the OSCE. This was an observational and crosssectional study and it was perfomed in 2018.

\section{Description of OSCE's Steps}

\section{OSCE Stations}

Six interdisciplinary stations were developed, approaching the contents of anatomy, biosafety, dentistry, periodontics, dental materials and radiology. The stations were developed to contain their respective evaluation criteria. For each station, a check-list was cognitive, affective and psychomotor capacities for performing specific tasks were examined. The test was conducted in a standardized manner, with a structured method divided into stations according to each discipline. Each student $(n=44)$ completed a six- station circuit (Table 1). Six students entered at the same time, and each of them went to a different station. They took turns until they completed a circuit.

Table 1. Description of the discipline, activity and check-list of each station

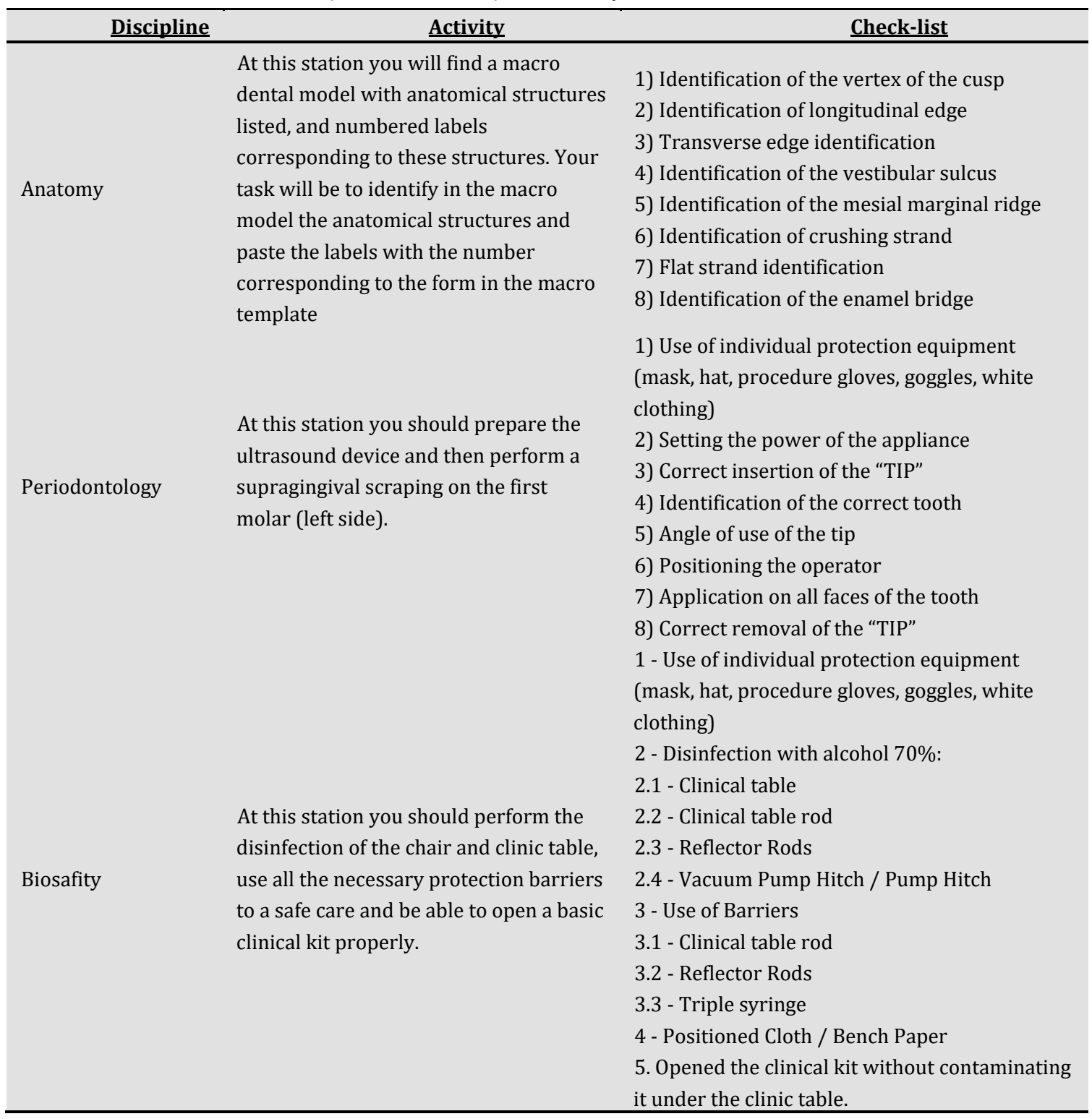




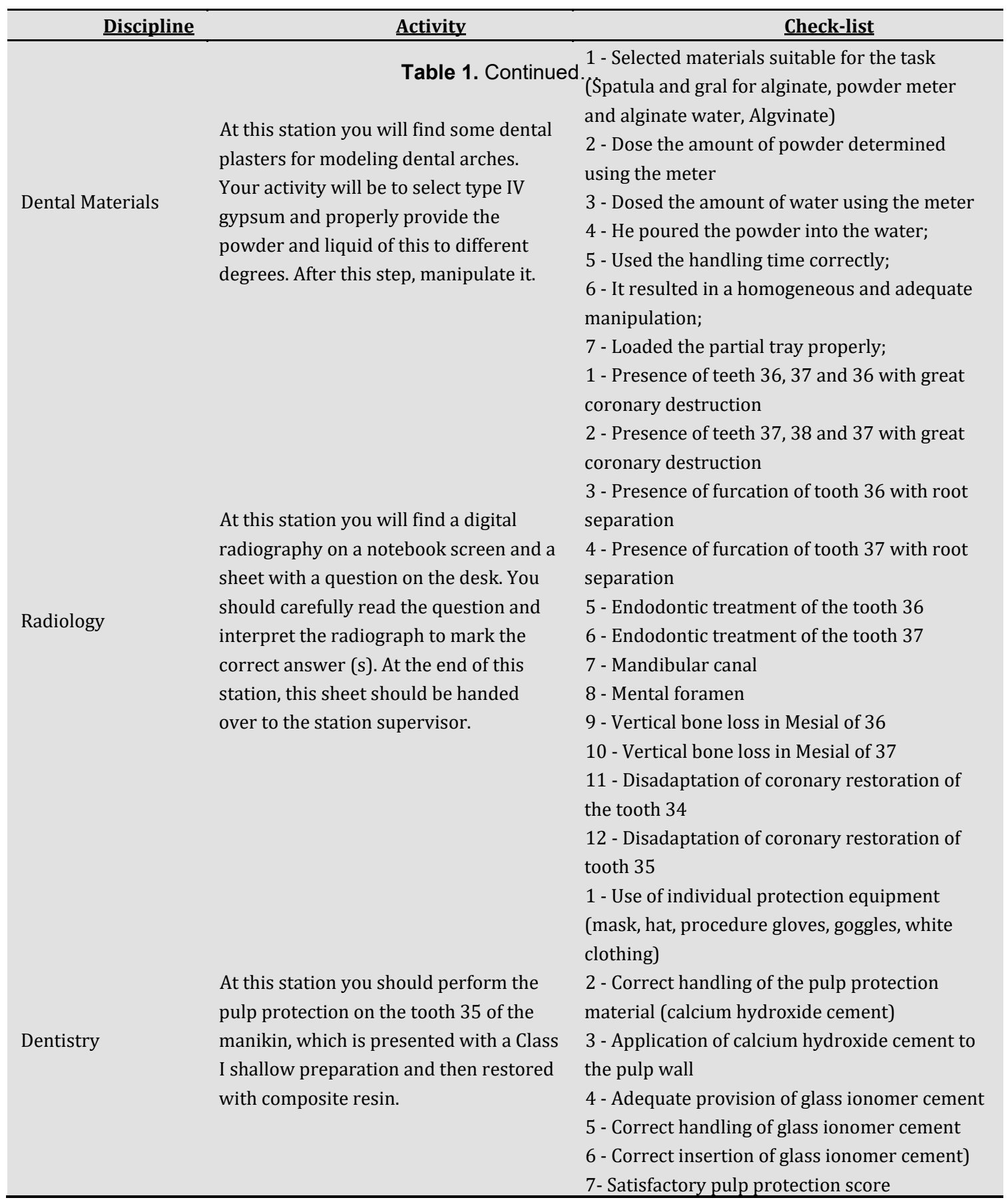

\section{Duration of Stations}

Each station lasted 6 minutes: one minute to read the purpose of the station, and five minutes to perform the task proposed. The students had to remain in the station for a total of 5 minutes, even if the completed the task in a shorter time. A sound alert went off to mark these time intervals and for continuity of the circuit.

\section{Check-List and Data Analysis}

In each station there were two examiners, who had a check-list as reference, to observe and evaluate each student. Scoring was calculated to obtain a final grade on a numerical scale of 
achievement. The results of the two examiner's assessments of each station were quantified, and the final score obtained was the arithmetic mean that was used as one of the assessment criteria of a curricular discipline of the mentioned course.

\section{Questionnaire}

At the end of the circuit, the examiners asked the students $(n=44)$ to fill in an anonymous questionnaire that contained questions relative to the degree of difficulty, time of performing the tasks, and the importance of the stations, impressions relative to the number of stations, organization and the total time of the OSCE. The questionnaire was adapted from Näpänkangas et al. ${ }^{15}$.

Regarding to each station, the following questions were done:

1) Regarding to the difficult degree, this station was:

a) Easy

b) Difficult

2) Regarding to time to carry out the activity of the station, the time was:

a) Extensive

b) Appropriate

c) Short

3) Regarding to station's importance, it was:

a) Very important

b) Important

c) Not very important

Regarding to the OSCE:

1) Regarding to the number of stations, OSCE presents:

a) Many stations

b) Appropriate number

c) Few stations

2) Regarding to the OSCE's organization, it was:

a) Very organized

b) Organized

c) Not very organized

3) Regarding to OSCE's total time, it was:

a) Extensive

b) Appropriate

c) Short 


\section{Feed-back}

After the end of the circuit by all students, there was a time of feed-back in which the teachersevaluators explained the criteria assessed in each station. The students were also encouraged to report their doubts and anxieties regarding to the process.

This study was approved by the Research Ethics Committee of the School of Medical and Health Sciences of Juiz de Fora (SUPREMA); Protocol No. 58497516.4/0000.5103. The results are presented as percentage distribution.

\section{RESULT}

The students ( $n=44 ; 35$ women and 9 men with a mean age of 20 years) filled out the questionnaire. They pointed out their impressions relative to the number of stations, organization and total time of duration of OSCE.

As regards the number of stations, $43(97.7 \%)$ of the students responded that this was appropriate. To the students, the OSCE process as a whole was very well organized $(n=25$; $56.8 \%)$, organized $(n=17 ; 38.6 \%)$ or not very organized $(n=1 ; 2.27 \%)$. One questionnaire was excluded because the student scored several alternatives. About the total time of the OSCE process, $29(65.9 \%)$ reported that it was appropriate; 10 (2.27\%) said that it was short; 4 (9.09\%), that it was long.

The students also filled out a questionnaire that contained questions relative to the degree of difficulty, time for performing the tasks and the importance of the content approached in each of the proposed stations (Figures 1, 2 and 3). The time attributed to each station was considered appropriate (65.9\%). Furthermore, the students considered that the topics and questions applied in each station were relevant.

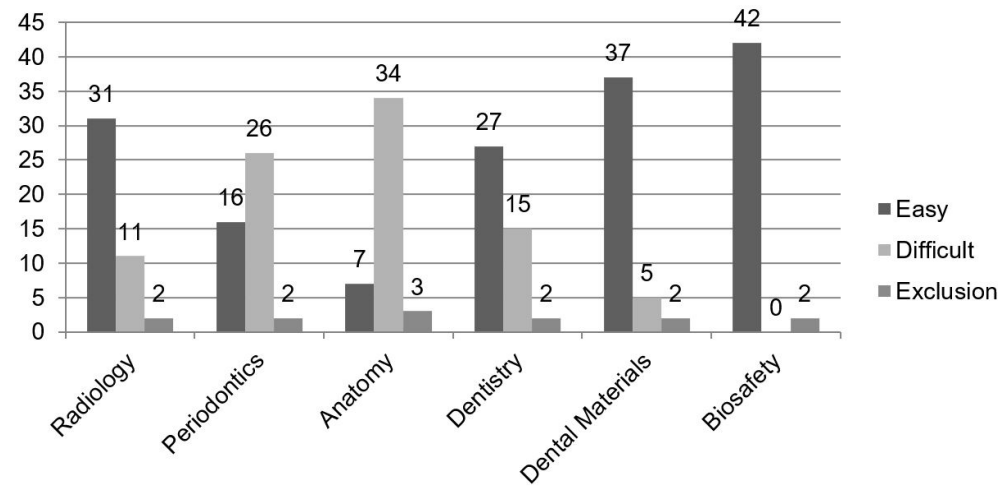

Figure 1. Quantification of the responses relative to the degree of difficulty of each station. Exclusion refers to some questions that presented more than one response marked.

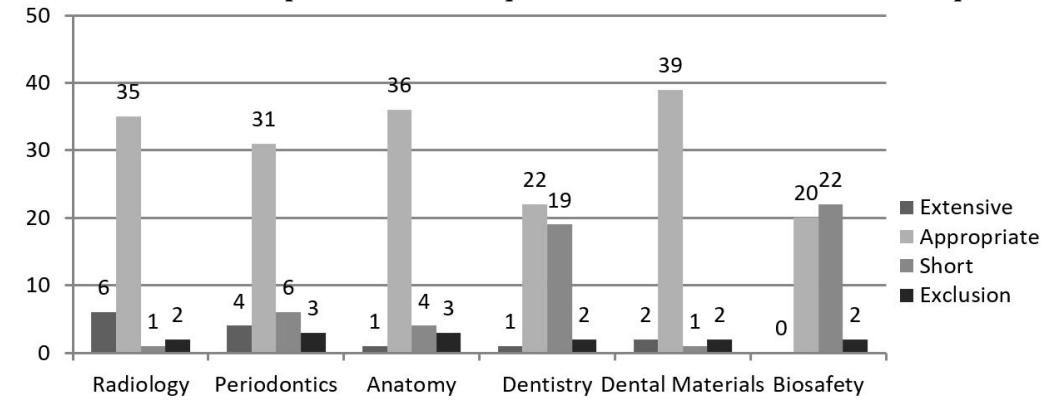

Figure 2. Quantification of the responses relative to the time available for each station. Exclusion refers to some questions that presented more than one response marked. 


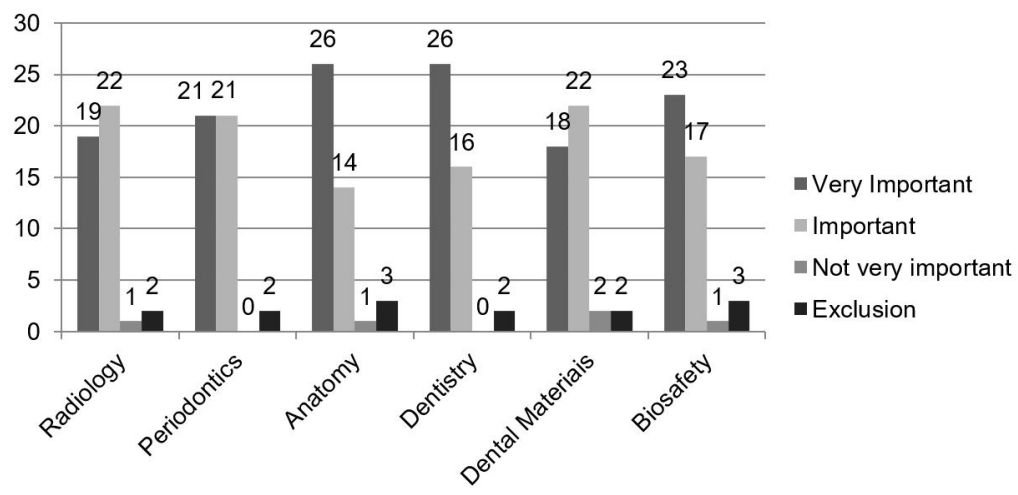

Figure 3. Quantification of the responses relative to the importance of the content approached in each station. Exclusion refers to some questions that presented more than one response marked.

\section{DISCUSSION}

The purpose of this study was to describe the stages of developing an OSCE for the Dentistry course and to find out the perception of students about this new assessment format, in comparison with the models previously used. OSCE is a summative assessment of students' graduation outcomes. The OSCE results are thought to predict the extent to which students had learned the related course material and their performance as general dentists ${ }^{16}$.

The specificities of the health area may be observed in the decisions to be taken, which involve the articulation of various fields of knowledge arising from the general education (with emphasis on scientific knowledge), professional education (with emphasis on technical knowledge) and work and social experiences (tacit qualifications) that are mediated by the ethical-political dimension ${ }^{17}$. Studies have shown that a positive correlation has been identified between the performance of undergraduate students in Dentistry in OSCE and their clinical and didactic performance, which corroborates the value of OSCE as an efficient and complete evaluative instrument ${ }^{18}$. However, OSCE has limitations in assessing students' capacity to perform clinical procedures, in large part because it is not feasible to ask students to perform invasive and nonreversible procedures on patients. This may be real or simulated yet students have a limited amount of time at each OSCE station to perform tasks, usually less than would be available in a real clinical setting for invasive or more complex procedures ${ }^{19,20}$.

Studies that have examined dental OSCEs from a student's perspective have similarly found that the examination is generally perceived favorably by students and seen to be a good test of clinical skills ${ }^{12,13}$. When dental OSCEs assess focused aspects of clinical skills rather than being comprehensive, they have also been viewed positively by students ${ }^{14,21}$. In this study, students' perception was positive, especially with regard to organization $56.8 \%$ considered the OSCE very organized and $38.6 \%$ organized); and the time attributed to each station $(65.9 \%$ of the students considered the time appropriate). Furthermore, the students considered that the topics and questions applied in each station were relevant. Although, another study ${ }^{15}$ considered the time allocated too short (63\%).

Regarding to the degree of difficulty of each station, two among the 6 stations - that of Periodontics and Anatomy - were considered difficult by the majority of the students, whereas, the other stations were considered easy. Similar results were found in the School of Dentistry of the University of Jordan ${ }^{14}$ with regard to organization of the OSCE, because $75 \%$ of the students judged the OSCE of Jordan organized; the time of stations appropriate (80.2\%) and considered a good portion of the stations easy (54.1\%). Another study ${ }^{15}$ evaluated the validity of the OSCE by measuring the attitude of examiners and dental students towards the OSCE and it was considered easy for $87 \%$ of the students. 
Planning, elaboration and application of the OSCE is far more complex and work-intensive than the conventional models of assessment ${ }^{22}$. It demands greater and integrated involvement of the staff members among the different disciplines, and more time dedicated from the time of planning through to application of the OSCE. To carry out the OSCE in a group of 44 students with a circuit of 6 stations, the involvement of 12 examiners in the morning shift, and 12 examiners in the afternoon shift was required. It was also necessary to consider the questions of logistics, physical area with the necessary space to mount the stations, as well and the material and instruments necessary, according to each station planned. For standardization and reliability of the exam, all the material was provided by the Institution. In relation to the quantity of stations, the Jordanian student considered the 67 stations a very high number ${ }^{14}$, differently from the students of this study, who judged the 6 station to be appropriate. Another study, considered 8 stations a good number with credible assessment results, and indices such as mean and discrimination coefficient of test scores from each station appropriated ${ }^{4}$. Therefore, the proposed protocol was found to be reliable and suitable.

Traditional teaching (written, oral assessments including essay and multiple-choice question [MCQ] examinations) has been criticized for focussing simply on abilities to memorize, ignoring manual clinical skills, hypothesis formation and decision-making as well as patient interaction ${ }^{23}$. Reorientation of education has been fostered by the Brazilian Public Policies of Education and Health, since the DCN, and in the case of graduation, passing through the Program of Reorientation of Professional Education in Health (Pró Saúde) and through the Program of Education for Working in the Area of Health (PET Saúde), with wide scope, in the undergraduate courses in health throughout Brazil24. Changes in student's evaluation generate many conflicts between administrators, teachers and students, but OSCE is set up to provide an objective evaluation of a student's performance by giving every student the same questions or scenarios from evaluators who rate student responses according to a standardized grading system, thus minimizing interexaminer error. Recently our understanding of dental education, including the OSCE, has been changing gradually ${ }^{14}$.

The strength of this study was the high student response rate. Students were asked to answer the questionnaire anonymously immediately after their last task. Only one questionnaire was excluded from the study due to student response being an array of alternatives. In addition to the limited number of stations available, the main limitation of our study was the small sample size, due to the number of students attending the same dental period (fourth) at our institution. New evaluations regarding the students' perception will be made and new data will be presented subsequently.

\section{CONCLUSION}

For the success of OSCE, it is primordial to plan stations that are relevant to clinical practice of the student; with a group of teachers involved in the teaching-learning process, and particularly, to appreciate the students' perception, thereby establishing the formative nature of this evaluation. The student's perception was positive especially regarding to organization and the time attributed to each station. Furthermore, the students considered that the topics and questions applied in each station were relevant.

\section{REFERENCES}

1. Bang JB, Choi KK. Correlation between clinical clerkship achievement and objective structured clinical examination (OSCE) scores of graduating dental students on conservative dentistry. Restor Dent Endod. 2013 May;38(2):79-84. http://dx.doi.org/10.5395/rde.2013.38.2.79. PMid:23741710. 
2. Shahzad A, Saeed MHB, Paiker S. Dental students' concerns regarding OSPE and OSCE: a qualitative feedback for process improvement. BDJ Open. 2017 Jun 9;3:17009. http://dx.doi.org/10.1038/bdjopen.2017.9. PMid: 29607080.

3. Silva ET, Nunes MF, Queiroz MG, Leles CR. Factors influencing student's performance in a Brazilian dental school. Braz Dent J. 2010 Jan;21(1):80-6. http://dx.doi.org/10.1590/S010364402010000100013. PMid:20464326.

4. Nie R, Zhu F, Meng X, Zhang H, Xie S, Wu L, et al. Application of OSCE for Stage Assessment in Standardized Training for Oral Residents. J Dent Educ. 2018 Sep;82(9):1000-6. http://dx.doi.org/10.21815/JDE.018.099. PMid:30173197.

5. Harden RM, Gleeson FA. Assessment of clinical competence using an objective structured clinical examination (OSCE). Med Educ. 1979 Jan;13(1):41-54. http://dx.doi.org/10.1111/j.13652923.1979.tb00918.x. PMid:763183.

6. Kilminster S, Roberts T. Standard setting for OSCEs: trial of borderline approach. Adv Health Sci Educ Theory Pract. 2004;9(3):201-9. http://dx.doi.org/10.1023/B:AHSE.0000038208.06099.9a. PMid:15316271.

7. Adeyemi-Doro HO, Bamisaiye A. A new course in basic therapeutic skills for medical and dental students at the College of Medicine, University of Lagos: student evaluation. Med Educ. 1983 Nov;17(6):354-9. http://dx.doi.org/10.1111/j.1365-2923.1983.tb01119.x. PMid:6633305.

8. Jebbin NJ, Adotey JM. An audit of basic practical skills acquisition of final year medical students in a Nigerian medical school. Ann Afr Med. 2012 Jan-Mar;11(1):42-5. http://dx.doi.org/10.4103/15963519.91021. PMid:22199047.

9. Mossey PA, Newton JP, Stirrups DR. Scope of the OSCE in the assessment of clinical skills in dentistry. Br Dent J. 2001 Mar;190(6):323-6. http://dx.doi.org/10.1038/sj.bdj.4800961. PMid:11325158.

10. Barman A. Critiques on the objective structured clinical examination. Ann Acad Med Singapore. 2005 Sep;34(8):478-82. PMid:16205824.

11. Wardman MJ, Yorke VC, Hallam JL. Evaluation of a multi-methods approach to the collection and dissemination of feedback on OSCE performance in dental education. Eur J Dent Educ. 2018 May;22(2):e203-11. http://dx.doi.org/10.1111/eje.12273. PMid:28524327.

12. Graham R, Zubiaurre Bitzer LA, Mensah FMA, Anderson OR. Dental student perceptions of the educational value of a comprehensive, multidisciplinary OSCE. J Dent Educ. 2014 May;78(5):694-702. PMid:24789829.

13. Larsen T, Jeppe-Jensen D. The introduction and perception of na OSCE with an element of self and peer-assessment. Eur J Dent Educ. 2008 Feb;12(1):2-7. http://dx.doi.org/10.1111/j.16000579.2007.00449.x. PMid:18257758.

14. Hammad M, Oweis Y, Taha S, Hattar S, Madarati A, Kadim F. Students' opinions and attitudes after performing a dental OSCE for the first time: a Jordanian experience. J Dent Educ. 2013 Jan;77(1):99104. PMid:23314473.

15. Näpänkangas R, Harila V, Lahti S. Experiences in adding multiple-choice questions to an objective structural clinical examination (OSCE) in undergraduate dental education. Eur J Dent Educ. 2012 Feb;16(1):e146-50. http://dx.doi.org/10.1111/j.1600-0579.2011.00689.x. PMid:22251338.

16. Bang JB, Choi KK. Correlation between clinical clerkship achievement and objective structured clinical examination (OSCE) scores of graduating dental students on conservative dentistry. Restor Dent Endod. 2013 May;38(2):79-84. http://dx.doi.org/10.5395/rde.2013.38.2.79. PMid:23741710.

17. Boterf GL. Evaluer la compétence d'un professionnel: trois dimensions à explorer. Personnel. 2004;451:18-21.

18. Park SE, Anderson NK, Karimbux NY. OSCE and case presentation as active assessments of dental student performance. J Dent Educ. 2016 Mar;80(3):334-8. PMid:26933109. 
19. Simon SR, Bui A, Day S, Berti D, Volkan K. The relationship between second-year medical students' OSCE scores and USMLE step 2 scores. J Eval Clin Pract. 2007 Dec;13(6):901-5. http://dx.doi.org/10.1111/j.1365-2753.2006.00768.x. PMid:18070260.

20. Muller ES, Harik P, Margolis M, Clauser B, Mckinley D, Boulet JR. An examination of the relationship between clinical skills examination performance and performance on USMLE step 2. Acad Med. 2003 Oct;78(10 Suppl):S27-9. http://dx.doi.org/10.1097/00001888-200310001-00009. PMid:14557087.

21. Lele SM. A mini-OSCE for formative assessment of diagnostic and radiographic skills at a dental college in India. J Dent Educ. 2011 Dec;75(12):1583-9. PMid:22184597.

22. Khan KZ, Gaunt K, Ramachandran S, Pushkar P. The objective structured clinical examination (OSCE): AMEE Guide No. 81. Part II: organisation \& administration. Med Teach. 2013 Sep;35(9):e1447-63. http://dx.doi.org/10.3109/0142159X.2013.818635. PMid:23968324.

23. Landes CA, Hoefer S, Schuebel F, Ballon A, Teiler A, Tran A, et al. Long term prospective teaching effectivity of practical skills training and a first OSCE in crânio maxillofacial surgery for dental students. J Craniomaxillofac Surg. 2014 Jul;42(5):e97-104. http://dx.doi.org/10.1016/j.jcms.2013.07.004. PMid:24012014.

24. Amaral E, Campos HH, Friedman S, Morahan PS, Araujo MN, Carvalho PM, et al. An educational international partnership responding to local needs: process evaluation of the Brazil FAIMER Regional Institute. Educ Health (Abingdon). 2012 Nov;25(2):116-23. http://dx.doi.org/10.4103/13576283.103459. PMid:23823595.

\section{CONFLICTS OF INTERESTS}

The authors declare no conflicts of interest.

\section{${ }^{*}$ CORRESPONDING AUTHOR}

Cleide Gisele Ribeiro, SUPREMA - Faculdade de Ciências Médicas e da Saúde de Juiz de Fora, Av. Barão do Rio Branco, 2406/506, Centro, 36016-310 Juiz de Fora - MG, Brasil, e-mail: cleidegr@yahoo.com.br

Received: March 15, 2019

Accepted: July 11, 2019 